\title{
Injunctions and compliance orders: some procedural issues
}

\author{
Richard Boast*
}

\section{What is an injunction?}

An injunction is a remedy originally devised in the Court of Chancery in England, mainly, it appears, for the purpose of bringing proceedings in the courts of common law to a halt and having the cases transferred to Chancery (Baker, 1979, pp. 90-91). Today it is an important judicial remedy used in many different situations, sometimes alone, sometimes in combination with other remedies such as damages. An injunction is a discretionary remedy, directed at a particular person, ordering that person to either do something (a mandatory injunction) or to stop doing or not to do something (a restrictive injunction). ${ }^{1}$ Since an injunction is an order of the High Court, a person who wilfully disobeys it - as is the case with any court order - has committed a contempt of court. Although such a contempt is a "civil" rather than a "criminal" contempt, the consequences can be exceptionally severe. The alleged contemnor can be fined or committed to jail by an order of the court, and can be detained in custody until the fines are paid or the order is complied with. Although matters are rarely taken so far, the threat of such alarming possibilities usually means that injunctions are instantly obeyed.

There are a number of sub-species of injunctions, of which the most familiar is the interim or interlocutory injunction. This is an injunction which is obtained to protect the status quo until such time as the court hears the substantive case. Quite frequently such interim injunctions will be renewed by consent of the parties and can thus remain in force for months or longer. Obtaining an interim injunction involves one or two day's very hard - and expensive - work from your solicitor, but generally one can be obtained relatively easily.

Courts approach the matter usually on the basis that, provided on the evidence there seems to be a genuine dispute, ("a serious issue to be tried" as it was put in the leading case of American Cyanimid v Ethicon) the status quo should be preserved. In American Cyanimid Lord Diplock states that "The court no doubt must be satisfied that the claim is not frivolous or vexatious; in other words, that there is a serious question to be tried."(p. 510) Then; 
where there is doubt as to the adequacy of the respective remedies in damages available to either party or to both, that the question of the balance of convenience arises... Where other factors appear to be evenly balanced it is a counsel of prudence to take such measures as are calculated to preserve the status quo." (p. 511).

The American Cyanimid approach has been specifically endorsed by the Court of Appeal in Consolidated Traders v Downes and has been applied in various industrial law cases by both the High Court and the Court of Appeal ${ }^{2}$.

The evidence will invariably be in the form of written statements (affidavits), which an efficient solicitor can prepare in a matter of hours. This affidavit evidence is not normally subject to cross- examination: usually there is not time for that. Sometimes the court will issue an injunction without the other side even knowing that the application has been filed: it is then said to be obtained ex parte. The court will do this if the judge believes that on the evidence before her the matter is either one of particular urgency, or there is not time to serve the papers on the other party. Again, this will have to be sufficiently documented in the affidavits, but in a suitable case that is not typically a problem for an experienced solicitor. Along with the application itself and the supporting affidavits it is necessary to file the statement of claim (of which more later) and an "undertaking as to damages". The latter is an undertaking to the effect that should a permanent injunction not be granted at the end of the substantive case the defendant will be indemnified against any loss caused to her by the interim injunction.In American Cyanimid the House of Lords explained the role of the undertaking as to damages as follows:

It is no part of the court's function at this stage of the litigation to try to resolve conflicts of evidence on affidavit as to facts on which the claims of either party may ultimately depend nor to decide difficult questions of law which call for detailed argument and mature considerations. These are matters to be dealt with at the trial. One of the reasons for the introduction of the practice of requiring an undertaking as to damages on the grant of an interlocutory injunction was that 'it aided the court in doing that which was its great object, viz abstaining from expressing any opinion on the merits of the case until the hearing.(p. 510).

Apart from an interim injunction, the other principal category is a permanent (or "final" or "perpetual") injunction - this being an injunction granted by the court not as an interim measure but as a final remedy once the main case has been heard. The usual remedy in civil cases is damages, but there are certain situations of "continuing" damage where an injunction is a proper remedy, usually issued as a supplement to, not in substitution of, damages. Another type of injunction is an injunction quia timet (lit. "because he fears"). This is an injunction issued to restrain future probable damage to property. The requirements here are a little more stringent: the court must be satisfied, for example, that the feared injury will be irreparable.

\section{Injunctions and contempt of court}


Non-compliance with a court order issued in the course of civil proceedings is classed as a "civil" contempt, which means that the party who claims to be disadvantaged by the alleged contempt has to take an additional step of bringing enforcement proceedings before the court. The court has a wide discretion as to what it can do. Often it will fine a person or body (such as a union) alleged to be in contempt rather than resort to the sanction of imprisonment, but the consequences can nevertheless be dire. An example is the 1986 Australian case of Australasian Meat Industry Employees Union v Mudginberri Station $P t y$. Ltd. Here an employer brought civil contempt proceedings against a union after it had ignored an interim injunction requiring it to desist from picketing. The union was fined $\$ 10000$ for the contempt and the court ordered it to additionally pay $\$ 2000$ per day for each day that the contempt continued. The union continued to picket the employer's premises, and by the time the court heard the substantive case the amount payable had reached a figure of $\$ 44000$. After the hearing the court issued a permanent injunction, but the union carried on with its defiance with the result that the court sequestrated its assets (to the amount of $\$ 2.3$ million), and the fines and costs were exacted from the sequestrated funds. The union would not comply with the final injunction either, which led to a further fine of $\$ 100000$ and a further round of sequestration proceedings.

The Labour Court is given a statutory power to punish for contempt in the face of the court (s. 281), this being criminal, not civil contempt - for example, threatening the judge or witnesses, or obstructing court proceedings. Otherwise the Labour Relations Act contains no further specific references to power to punish for contempt. Section 278, however, stipulates that the Court shall have "all the powers inherent in a Court of record". Although there is possibly some ambiguity as to whether the Labour Court is a "superior" or an "inferior" court of record - which category it is in will affect its ability to punish for contempt - it seems safe to say that the Labour Court has the same powers to punish for contempt as does the High Court. If so, it can fine, imprison and sequester in order to enforce its own orders: Whether the Court will take such steps is a different matter, but of its power in this regard there is little doubt.

\section{Causes of action}

An application for an injunction must be based on an alleged breach of the law - for instance that a contract has been breached, or that a tort is about to be, or has been, committed. (Torts are civil wrongs other than breaches of contract: examples are negligence, nuisance, trespass, defamation.) When seeking an interim injunction a statement of claim relating to the substantive case has to be filed along with all the other documents. The court must be satisfied that the application is based on some recognised, and properly documented, breach of law. Again, this requirement is not too difficult for a good solicitor to comply with, although preparing the statement of claim will usually be the most taxing of the many tasks she will have to do at short notice in order to obtain an interim injunction. In the labour law field she will be assisted in this task by the especially complex and intractable nature of the main tort actions governing industrial disputes.

It is not even clear exactly how many of these so-called "economic torts" there are, let alone what their precise scope is. The Labour Relations Act gives to the Labour Court exclusive jurisdiction for tort actions "where a strike or lockout is occurring or has occurred and as a result proceedings are issued against any party to the strike or lockout" (s. 242). ("Strike", be it noted, is defined very widely indeed in s. 231.) The four torts listed in section 242 of the Act are conspiracy, intimidation, inducement of breach of contract, and interference by unlawful means with trade, business or employment. The law relating to these torts is notably difficult and obscure, compounded by the fact that 
most of the case-law has developed in the United Kingdom where the general structure of labour law is very different from that in this country. Determining how the economic torts ought to be applied here requires a thorough grasp of the many differences in the legal position of trade unions in New Zealand and the United Kingdom. To devise something that at least looks like a proper cause of action out of this legal morass is a relatively easy task. A little knowledge can be made to go a very long way. At short notice a judge will be unable to tell whether the facts set out in the affidavits and the statement of claim fit within the legal definitions of the economic torts or not. This could take days of legal argument to clarify, supposing it is capable of clarification. At the stage of hearing an application for an interim injunction a judge will usually have little choice but to accept the statement of claim at face value.

This is worth emphasising in view of the fact that the "labour injunction", as it is styled, is not a wholly respectable procedure. Many commentators - such as Wedderburn (1986, ch. 8)- point out, quite correctly, that the real purpose of an interim injunction in the industrial arena is to bring a strike to an end, not to hold the status quo until the issues can be traversed at the hearing of the main case. The substantive case is a fiction: more often than not, it never takes place. Certainly the ambiguities and complexities surrounding the law on the economic torts greatly facilitates the use of the interim injunction in this manner, although whether to use the procedures in such a way is "improper" is a moot point. Bringing proceedings for an interim injunction while never seriously intending to proceed with the substantive case is certainly not a practice confined to the area of labour law.

The use of the interim injunction as a weapon in industrial relations is a practice which has developed out of a sequence of historical accidents. The interim injunction was never specifically designed by the courts to deliberately make life difficult for unions. Although union defendants to interim injunctions undoubtedly do face a number of very real tactical disadvantages, this is attributable to a combination of historical and procedural circumstances, not deliberate judicial policy. It is questionable whether it should have been the task of the ordinary courts to create a workable legal structure for industrial relations. However with the Labour Relations Act 1987 our legislators, as part of a supposedly rational design, have given statutory sanction to the role of labour injunctions by specifically giving to the Labour Court an exclusive jurisdiction to hear and determine them. Clearly our legislators, at least, believe that the labour injunction has a proper place in a rational scheme of industrial law. It is, however, not easy to see what that place might be.

\section{Matters of evidence and proof}

The proper approach to be taken by a court when it has been requested to issue an interim injunction, according to the House of Lords in the American Cyanimid decision, involves a two-stage process. First, it must ask whether, on the evidence before it, there is a serious issue to be tried. As indicated already, it is not too difficult for counsel for an applicant in an industrial law case to at least create the impression that there is an issue to be tried. Then the court must inquire about the "balance of inconvenience". Who will be most inconvenienced if the injunction is refused? Usually there can only be one answer. The employer who has filed a thick affidavit listing the probable losses that will occur to his business in the event of a strike has an obvious tactical advantage over a union. The "inconvenience" likely to be faced by the union is rather hard to explain to a High Court judge or to document in an affidavit. Nor is the position significantly affected by the transference of jurisdiction to the Labour Court, as will be seen. What is the "inconvenience" to a union? A risk of declining living standards for its members perhaps? 
This, of course, is a long-term matter which is difficult to balance against the immediate risks to an employer. This does seem to indicate that in this context the interim injunction in an inherently unfair weapon.

The balance of proof, as in all civil cases, falls on the applicant or plaintiff. The appropriate standard is the civil standard of the balance of probabilities, a much less demanding requirement than the standard of proof required in a criminal case. In this context what has to be proved is more significant than the standard of proof itself. The applicant must convince the court on the balance of probabilities that there is a serious issue to be tried, and that he will be more inconvenienced than the respondent in the event of the injunction being refused. These are not difficult obstacles.

\section{The Labour Court and injunctions}

One important effect of the 1987 Act has been to remove from the High Court injunction proceedings and tort actions arising out of strikes and lockouts. These are now vested in the exclusive jurisdiction of the Labour Court. Obviously the objective is to benefit from the specialist skills and experience of the Labour Court judges.

The Labour Court has the power to make its own rules, by section 307. Section 307(2), which deals with the procedures governing injunctions, economic torts and applications for review, provides:

To the extent that the Labour Court does not make rules under subsection (1) of this section regulating the practice and procedure of the Court under section 242 and section 243 and section 280 of this Act, proceedings in the Labour Court under those sections shall be regulated by the rules applicable to proceedings founded on tort, injunctions, and judicial review in the High Court, as far as they are applicable and with all necessary modifications.

This therefore empowers the Court to make its own rules relating to injunction proceedings; to the extent that it has not done so the procedures of the High Court will continue to apply. I understand that the Labour Court does not intend to issue any procedural rules of its own, however, but will instead apply the High Court rules. ${ }^{3}$ Procedurally, then, nothing has changed.

Although the Court is empowered to decide the cases that come before it "in equity and good conscience" (see s. 279(4), and s. 303), this does not apply to matters arising under section 242 (economic torts), section 243 (injunctions) and section 280 (applications for review). ${ }^{4}$ Moreover, by section 309 any party to any proceedings founded on the economic torts can appeal to the Court of Appeal "against any interlocutory or final order of the Labour Court in the proceedings". Taken together, these various sections mean that the approach of the Labour Court to injunction proceedings must be essentially the same as the High Court. A relatively strict adherence to precedent and legal formality is required. It is legitimate to wonder why the effort was made to transfer these proceedings to the Labour Court in the first place. The forum for hearing labour injunctions has 
changed its name, but nothing else. In view of the statutory constraints placed on the Labour Court, it is hard to see how the special experience of the judges can be put to use.

Procedurally, then, there have been no changes. In terms of substantive law, however, there has been a major change. The effect of s. 243(3) and s. 233 is that no proceedings relating either to injunctions or to the economic torts can be brought for strikes or lockouts arising out of "lawful" disputes of interest. This terminology requires some careful consideration, as the statutory definitions of "disputes of interest", "lawful strikes" and "unlawful strikes" are all rather complicated. I will move through the definitions step by step.

(a) "Disputes of Interest" and "Disputes of Rights" -

This is familiar terminology and the respective definitions are set out in s. 2 , the definition section of the Act. A dispute of interest is a dispute between an employer and a union "created with intent to procure an agreement or award". A dispute of rights means a dispute "concerning the interpretation, application, or operation of an agreement".

(b) "Lawful" Strikes and Lockouts -

A strike is "lawful" when:

- It relates to a dispute of interest provided that the date of expiry of the existing award or agreement is not more than 60 days after the date of the agreement (s. 233(1)(a));

It relates to a dispute of rights "created with intent to procure an award or agreement to cover workers not currently covered by an award or agreement" (s. 233(1)(b));

- $\quad$ It relates to a "new matter" (s. 233(1)(c));

- It relates to a redundancy agreement where there is no redundancy agreement in existence, and "the only workers involved in the strike are those of the employer to whom the redundancy agreement will apply" (s. 233(1)(d)).

(c) "Unlawful" Strikes and Lockouts

Section 234(1) stipulates that a strike or lockout shall be unlawful if it concerns -

A dispute of rights: or

A personal grievance that can be submitted to a grievance committee or the

Labour Court; or

Demarcation issues; or

Union membership; or

Cancellation of a union's registration under this Act.

Clearly a great deal turns on whether a strike is classed as "lawful" or "unlawful". It should be remembered that when seeking an interim injunction all that is necessary is that the applicant convinces the court that on the "balance of probabilities" there is a "serious issue" as to whether a strike is, or is not, unlawful. How much of an impediment this is likely to be remains to be seen. Creating an impression from the documents that a strike is possibly unlawful is not likely to baffle the ingenuity of a good lawyer for too long.

Even if a strike is "unlawful" it does not follow that an employer will necessarily succeed in his substantive claim for damages. The effect of a strike being classed as "unlawful" means merely that the union loses its statutory immunity. The employer will still need to establish that the union is liable at common law. It will have to be shown that the 
union's actions fall within the kinds of conduct proscribed by the economic torts, and that none of the recognised common-law defences, such as justification, apply. 5

\section{Compliance orders}

A compliance order is in essence a simplified kind of injunction. The Labour Court is, by s. 207, empowered to order compliance "with any provision of this Act, or of any award or agreement or of any rule of a union", or with orders of the Labour Court itself, of the Arbitration Commission, or of a grievance committee or the Registrar of Unions. Such proceedings can be brought by any person or organisation who has been "prejudicially affected" by the non-compliance (s. 207(2) ). This statutory definition of who has the right to bring an application for a compliance order contrasts with the situation regarding injunctions, where the common-law rules about who has standing to bring proceedings are left unaltered by the Act.

The consequences of failing to comply with an order are set out in s.207(7). These include imprisonment for a term not exceeding three months, or a fine of not more than $\$ 5,000$ : somewhat less fearsome than the consequences of being in contempt of court. The availability of the new remedy of a compliance order does raise once again the question of why injunction proceedings have been retained in the industrial arena.

\section{Conclusion}

In relation to interim injunctions there have been no procedural changes of any kind. This will mean that the well-recognised tactical disadvantages faced by a trade union defendant to injunction proceedings will simply be perpetuated. Although there has been a major change to the substantive law of labour injunctions, in that it is now no longer possible to obtain an interim injunction for a strike arising out of a dispute of interest, it is probable that this will not seriously hamper injunction proceedings at the interlocutory stage

\section{References}

Baker, J (1979) An introduction to English legal history 2nd ed., London.

Wedderburn, Lord (1986) The worker and the law Harmondsworth, Penguin.

\section{List of cases}

American Cyanimid v Ethicon [1975] 1 All ER 504 (HL).

Australasian Meat Industry Employees Union v Mudginberri Station Pty. Ltd. (1986) 66 ALR 577.

The New Zealand Courts appear willing to give the "defence" of justification a much wider scope than is the case in the UK Speight J.'s decision in Pete's Towing Services v Northern Drivers is noteworthy in allowing a defence of justification of reasonably wide scope to the tort of interference with breach of contractual relations. 
Columbus Maritime Services Ltd v New Zealand Seamens Union IUW and Federated Cooks and Stewards IUW, High Court, Auckland, 16 August 1983 (A730/83).

Consolidated Traders v Downes [1981] 2 NZLR 247 (CA).

Harder v NZ Tramways Union [1977] 2 NZLR 162.

Mid-Canterbury Stores v Canterbury Stores Union, High Court, Christchurch, 20 August 1982 (CA 178/82).

New Zealand Baking Trades Employees' IUW v General Foods Corporation (N.Z.) Ltd. [1985] 2 NZLR 110.

Pete's Towing Services v Northern Drivers [1970] NZLR 32. 